\title{
PENGARUH MODEL THINK PAIR SHARE BERBANTUAN MULTIMEDIA INTERAKTIF TERHADAP MOTIVASI BELAJAR IPA DAN KETERAMPILAN BERPIKIR KRITIS SISWA SMK N 1 SINGARAJA
}

\author{
Putu Ayu Paryawati ${ }^{1}$, I Wayan Santyasa², I Wayan Sukra Warpala³ \\ ${ }^{123}$ Program Studi Teknologi Pembelajaran, Program Pascasarjana, \\ Universitas Pendidikan Ganesha \\ Singaraja, Indonesia
}

e-mail: ayu.paryawati@pasca.undiksha.ac.id, wayan.santyasa@pasca.undiksha.ac.id, sukra.warpala@pasca.undiksha.ac.id

\begin{abstract}
Abstrak
Penelitian ini bertujuan mendeskripsikan perbedaan (1) motivasi belajar (MB) IPA dan keterampilan berpikir kritis (KBK) siswa antara siswa yang belajar dengan model think pair share berbantuan multimedia interaktif (TPSMI), think pair share (TPS), dan pembelajaran langsung (PL), (2) MB IPA antara siswa yang belajar dengan Model TPSMI, TPS, dan PL, (3) KBK antara siswa yang belajar dengan model TPSMI, TPS, dan PL. Penelitian ini menggunakan desain quasi eksperimen dengan rancangan non equivalent pretest-posttest control group design. Kovariabel yang diteliti adalah MB awal dan KBK awal. Populasinya adalah 4 kelas siswa kelas X SMK N 1 Singaraja Tahun Pelajaran 2015/2016. Pemilihan sampel dilakukan dengan teknik cluster random sampling. Sampel dalam penelitian ini terdiri dari 3 kelas (XA UPW, XB UPW, XC UPW) dengan jumlah siswa 126 orang. Data kovariabel dikumpulkan sebelum perlakuan, sedangkan data variabel dependen dikumpulkan pada akhir perlakuan, yang selanjutnya dianalisis dengan statistik deskriptif dan Uji MANCOVA. Setelah perlakuan dikontrol dengan kovariabel MB dan KBK awal, hasil penelitian menunjukkan temuan-temuan sebagai berikut. (1) Terdapat perbedaan secara signifikan MB dan KBK antara siswa yang belajar dengan model pembelajaran kooperatif TPSMI, TPS, dan PL. (2) Terdapat perbedaan secara signifikan MB antara siswa yang belajar dengan TPSMI, TPS, dan PL. (3) Terdapat perbedaan secara signifikan KBK antara siswa yang belajar dengan TPSMI, TPS, dan PL. Hasil uji lanjut dengan LSD menunjukkan bahwa model TPSMI lebih unggul dibandingkan dengan model TPS dan model PL dalam pencapaian MB dan KBK.
\end{abstract}

Kata Kunci: model think pair share, motivasi belajar IPA, keterampilan berpikir kritis.

\begin{abstract}
The aim of the research was to describe the differences of (1) learning motivation (LM) and critical thinking skill (CTS) between students who learned with Think Pair Share model aided with Interactive Multimedia (TPSIM), Think Pair Share (TPS), and students who learned by direction instruction (DI); (2) LM between student who learned with TPSIM, TPS, and students who learned DI; 3) CTS between students who learned with TPSIM, TPS, and students who learned by DI. This quasi experiment used pretest-post test only control design. This research utilized pre LM and pre CTS as covariables. The population were four majors of $10^{\text {th }}$ grade High School of SMK N 1 Singaraja in the academic year 2015/2016. By using cluster group random sampling, there have been chosen three classes (XA UPW, XB UPW, XC UPW) samples with a total of 126 students. The data of covariables was collected before treatment, but the data of devendent variables were collected at the end of treatment and then it was analyzed descriptively and with MANCOVA test. After the treatment was controlled by te covariables, the result of research were as followes. (1) There was a significant difference of LM and the CTS between the students who learned using TPSIM, TPS and DI. (2) There was a significance difference of LM between the students learned in the TPSMI model, TPS, and DI. (3) There was a significance difference
\end{abstract}


of CTS between the students learned in the TPSIM model, TPS and DI. The result of the LSD showed that the TPSIM is better than the TPS model, and as well as the DI in achieving both LM and CTS.

Key words: think pair share model, learning motivation science, critical thinking skill

\section{PENDAHULUAN}

Perkembangan era globalisasi menuntut peserta didik menguasai informasi di bidang teknologi. Perkembangan ilmu pengetahuan dan teknologi semakin mendorong upaya-upaya pembaharuan dalam pemanfaatan hasil-hasil teknologi dalam proses belajar. Teknologi yang tepat seperti media pembelajaran sangat mendukung perkembangan IImu Pengetahuan Alam (IPA) dalam proses pembelajaran. Tanpa media yang tepat proses pembelajaran IPA yang terjadi kurang bermakna. Pembelajaran yang bermakna akan tercapai apabila didukung oleh perencanaan yang matang dari praktisi pembelajaran. Kebermaknaan proses pembelajaran akan mendukung Sistem Pendidikan Nasional No.2 Tahun 1989 bagi peserta didik untuk mendapatkan pelayanan pendidikan sesuai dengan bakat, minat dan kemampuannya. Bakat, minat dan kemampuan siswa bisa dicapai dan berkembang jika dalam proses pembelajaran dipilih strategi yang tepat yang tertuang dalam tujuan pembelajaran, dilaksanakan dengan memperhatikan sarana prasarana, jenis media yang digunakan, materi yang diberikan, dan metodologi. Pembelajaran bermakna dapat meningkatkan kualitas pembelajaran yaitu dengan cara membuka lebar-lebar terhadap akses ilmu pengetahuan dan penyelengaraan pendidikan bermutu. Peningkatan mutu pendidikan dapat diupayakan melalui pembaharuan kurikulum, peningkatan kualitas guru, pelatihan model-model pembelajaran, pemenuhan sarana prasarana belajar. Menurut Human Development Report 2007-2008, Human Development Indeks (HDI) Indonesia sebesar 0,728 (HDI $>0,900=$ tinggi, dan $\mathrm{HDI}<0,900=$ rendah), yang berada dalam peringkat 107 dari 177 negara yang disurvei oleh UNDP (Kuncoro, 2009). Indeks pendidikan mencapai 0,83

karena angka melek huruf sebesar 90,4\% dan rata-rata rasio masuk sekolah dari SD sampai SMU mencapai 68,2\%. Dengan kata lain, belum seluruh rakyat Indonesia "merdeka dari kebodohan". Berdasarkan data yang dilaporkan oleh TIMMS (Trend International Mathematics and Science Study) prestasi siswa Indonesia di Asia Tenggara tergolong sangat rendah (Yuwono, 2009). Hal itu dapat dilihat pada posisi Indonesia rata-rata 411 (400, rendah), Malaysia rata-rata 508 (475, menengah), Singapura rata-rata 605 (625, tingkat lanjut). Hal ini menunjukkan bahwa output dari pendidikan Indonesia belum mencapai hasil yang maksimal, di mana hal ini juga menunjukkan bahwa belum maksimalnya pemahaman siswa terhadap konsep-konsep yang diajarkan.

Kenyataan tersebut juga didukung oleh proses pembelajaran yang terjadi saat ini di sekolah. Proses pembelajaran lebih berorientasi pada upaya pengembangan dan menguji daya ingat siswa sehingga kemampuan berpikir siswa direduksi dan sekedar dipahami sebagai kemampuan mengingat. Selain itu, hal tersebut juga berakibat siswa terhambat dan sulit menghadapi masalah-masalah yang menuntut pemikiran dan pemecahan masalah yang lebih kompleks. Model pendidikan formal tersebut apabila terus dipertahankan akan berfungsi membunuh kemampuan berpikir tingkat tinggi siswa karena lebih banyak mengedepankan aspek ingatan saja.

Menyikapi hal tersebut berbagai
upaya yang dilakukan pemerintah
diantaranya penyempurnaan kurikulum.
Perubahan kurikulum didasari pada
kesadaran bahwa perkembangan dan
perubahan yang terjadi dalam kehidupan
bermasyarakat, berbangsa dan bernegara
di Indonesia tidak terlepas dari pengaruh
perubahan global, perkembangan ilmu
pengetahuan dan teknologi, serta seni dan
budaya. Perubahan secara terus menerus


ini menuntut perlunya perbaikan sistem pendidikan nasional, termasuk penyempurnaan kurikulum untuk mewujudkan masyarakat yang mampu bersaing dan menyesuaikan diri dengan perubahan. Perubahan-perubahan dibidang pendidikan terus dilakukan untuk memperbaiki mutu pendidikan, salah satunya adalah penyempurnaan kurikulum. Kurikulum 2006 disempurnakan menjadi kurikulum 2013 yang diharapkan dapat membentuk karakter dan kepribadian peserta didik menjadi lebih baik dalam hal sikap, pengetahuan, dan keterampilan.

Kurikulum 2013 dikembangkan dengan penyempurnaan pola pikir sebagai berikut: 1) pola pembelajaran yang berpusat pada guru menjadi pembelajaran berpusat pada peserta didik. Peserta didik harus memiliki pilihan-pilihan terhadap materi yang dipelajari untuk memiliki kompetensi yang sama; 2) pola pembelajaran satu arah (interaksi guru-peserta didik) menjadi pembelajaran interaktif (interaktif gurupeserta didik-masyarakat-lingkungan alam, sumber/ media lainnya); 3) pola pembelajaran terisolasi menjadi pembelajaran secara jejaring (peserta didik dapat menimba ilmu dari siapa saja dan dari mana saja yang dapat dihubungi serta diperoleh melalui internet); 4) pola pembelajaran pasif menjadi pembelajaran aktif-mencari (pembelajaran siswa aktif mencari semakin diperkuat dengan model pembelajaran pendekatan sains); 5) pola belajar sendiri menjadi belajar kelompok (berbasis tim); 6) pola pembelajaran alat tunggal menjadi pembelajaran berbasis alat multimedia; dan 7) pola pembelajaran pasif menjadi pembelajaran kritis ( Suharto, 2015).

Harapan selanjutnya peserta didik mampu mengembangkan potensi dirinya dalam sikap, pengetahuan, dan keterampilan. Pengembangan diri tersebut sangat diperlukan untuk hidup bermasyarakat, berbangsa, serta berkontribusi pada kesejahteraan hidup umat manusia. Kegiatan pembelajaran perlu menggunakan prinsip yang: (1) berpusat pada peserta didik, (2) mengembangkan kreativitas peserta didik, (3) menciptakan kondisi menyenangkan dan menantang, (4) bermuatan nilai, etika, estetika, logika, dan kinestetika, dan (5) menyediakan pengalaman belajar yang beragam melalui penerapan berbagai strategi dan metode pembelajaran yang menyenangkan, kontekstual, efektif, efisien, dan bermakna (Harsono, 2004).

Pembelajaran yang mampu memfasilitasi pebelajar untuk mengembangkan kecakapan hidup dan siap terjun di masyarakat adalah (1) peran pengajar lebih sebagai fasilitator, pembimbing, konsultan, dan kawan belajar, (2) jadwal fleksibel, terbuka sesuai kebutuhan, (3) belajar diarahkan oleh pebelajar sendiri, (4) berbasis masalah, proyek, dunia nyata, tindakan nyata, dan refleksi, (5) perancangan dan penyelidikan, (6) kreasi dan investigasi, (7) kolaborasi, (8) fokus masyarakat, (9) komputer sebagai alat, (10) presentasi media dinamis, (11) penilaian kinerja yang komprehensif (Santyasa, 2012).

Dalam upaya memperbaiki mutu pendidikan utamanya pada mata pelajaran IPA sangat perlu kiranya dilakukan perbaikan cara pembelajaran. Salah satunya adalah perbaikan pembelajaran dengan menggunakan model think pair share berbantuan multimedia interaktif dalam meningkatkan motivasi belajar dan keterampilan berpikir kritis.

Multimedia interaktif pada model mengajar think pair share merupakan alat bantu mengajar yang turut mempengaruhi kondisi pemahaman pembelajar tentang materi yang diajarkan dengan bahan pengajaran yang menarik dan juga menyenangkan $\mathrm{Hal}$ ini dilandasi oleh persepsi bahwa pembelajaran akan berlangsung dengan baik, efektif dan menyenangkan jika didukung oleh media pembelajaran yang menarik minat dan perhatian siswa serta dapat mengakomodasi berbagai gaya belajar siswa serta mampu menyediakan lingkungan belajar yang adaftif dan variatif yang bermuara pada hasil belajar siswa dalam hal motivasi dan keterampilan berpikir siswa. Hal ini sesuai dengan pendapat Heinich (dalam Iwantara, 2013) menyatakan penggunaan media berbasis multimedia dalam pembelajaran mendatangkan banyak manfaat, yaitu proses pembelajaran dapat berjalan lebih 
baik, lebih interaktif serta kualitas belajar dapat ditingkatkan.

Menurut Ali (2002) dan Setiawan (2007) bahwa pembelajaran multimedia interaktif merupakan suatu model pembelajaran yang dapat digunakan untuk menyalurkan pesan (message), merangsang pikiran, perasaan, perhatian dan kemauan siswa sehingga dapat mendorong proses belajar. Sehingga dengan adanya media pembelajaran multimedia interaktif diharapkan dapat memacu hasil belajar siswa. Ini sejalan dengan hasil penelitian yang dilakukan oleh Permana, et al (2015), dengan model pembelajaran 5E Learning Cycle berbantuan multimedia interaktif menemukan bahwa hasil belajar siswa lebih baik daripada siswa yang hanya diajar dengan model pembelajaran 5E Learning Cycle tanpa bantuan multimedia interaktif.

Karakteristik multimedia interaktif yang digunakan sebagai pendukung model belajar think pair share yaitu 1) memiliki lebih dari satu media yang konvergen, seperti adanya kombinasi dari teks, grafik, suara, dan animasi, 2) bersifat interaktif, dalam pengertian memiliki kemampuan untuk mengakomodasi respon peserta didik, 3) bersifat mandiri, dalam pengertian memberi kemudahan dan kelengkapan isi sedemikian rupa sehingga pengguna bisa menggunakan tanpa bimbingan orang lain.

Selain media pembelajaran, faktor lain yang dapat mendorong siswa untuk meningkat hasil belajarnya adalah adanya faktor pendorong internal dari dalam diri siswa yang dikenal dengan motivasi belajar. Menurut Kemp dan Dayton ,1985 media pembelajaran dapat memenuhi tiga fungsi utama, yakni: a) memotivasi minat dan tindakan; b) menyajikan informasi: dan c) memberikan instruksi. Untuk memenuhi fungsi motivasi, media pembelajaran dapat direalisaikan dengan teknik drama atau hiburan. Hasil yang diharapkan adalah melahirkan minat dan merangsang para siswa atau pendengar untuk bertindak (turut memikul tanggungjawab, melayani secara sukarela, atau memberikan sumbangan material). Pencapaian tujuan ini akan memengaruhi sikap, nilai dan emosi. Untuk tujuan informasi, media pembelajaran dapat digunakan dalam rangka menyajikan informasi di hadapan sekelompok siswa. Isi dan bentuk penyajian bersifat umum, berfungsi sebagai pengantar, ringkasan laporan atau pengetahuan latar belakang.

Motivasi adalah proses yang memberi semangat, arah, dan kegigihan perilaku (Santrock, 2008). Hal tersebut dapat diartikan perilaku yang termotivasi adalah perilaku yang penuh energi, terarah, dan bertahan lama. Hal senada juga disampaikan oleh Glynn \& Koballa (dalam Iwantara, 2013) yang menyatakan motivasi adalah sesuatu yang ada dalam diri siswa yang bersifat membangun, mengarahkan, dan mendukung perilaku siswa. Motivasi ada dua jenis, yaitu motivasi intrinsik dan motivasi ekstrinsik (Djamarah, 2002). Motivasi intrinsik adalah motivasi yang muncul dari dalam diri seseorang untuk melakukan sesuatu. Motivasi ekstrinsik adalah motivasi yang aktif karena adanya rangsangan dari luar.

Siswa sebagai individu yang unik sudah tentu memiliki motivasi belajar yang berbeda dengan teman-temannya dalam satu kelas. Motivasi belajar yang dimiliki oleh siswa akan memberikan dampak atau pengaruh yang positif apabila disediakan lingkungan dan kondisi belajar yang tepat, sehingga siswa dapat belajar secara optimal. Siswa yang belajar secara optimal akan mencapai hasil belajar yang baik. Namun jika kondisi atau lingkungan belajar siswa tidak sesuai dengan motivasi belajar yang dimilikinya akan membuat siswa tidak dapat belajar secara optimal. Hal ini akan berdampak negatif pada hasil belajar siswa itu sendiri. Oleh karena itu, selama proses pembelajaran di kelas, guru harus memperhatikan motivasi belajar yang dimiliki oleh siswa.

Motivasi belajar memegang peranan penting dalam proses pembelajaran. Siswa yang memiliki motivasi belajar tinggi dari dalam dirinya akan lebih mudah mengikuti proses pembelajaran karena siswa merasa pembelajaran itu penting. Siswa yang memiliki motivasi rendah akan tampak lebih tidak bergairah dalam mengikuti pembelajaran. Hal tersebut akan berdampak pada pencapaian hasil belajar siswa yaitu keterampilan berpikir kritis siswa. 
Keterampilan berpikir kritis merupakan salah satu outcome yang diharapkan dari pendidikan (Hudgins \& Hedelman (1988); Halpern (1993); dalam Semerci, 2005). Semerci (2005) mengungkapkan bahwa berpikir kritis merupakan sebuah kemampuan yang membantu siswa untuk yakin dalam membuat keputusan untuk hidup mereka. Dengan kata lain, berpikir kritis dapat meningkatkan kemampuan siswa untuk menyesuaikan diri dengan situasi baru, mengembangkan kapasitas penilaian dirinya, serta membantu siswa untuk memperoleh informasi dan melalui pertentangan yang sulit. Jadi, terdapat hubungan yang erat antara motivasi belajar dengan pencapaian hasil belajar siswa.

$$
\text { Berdasarkan penelitian yang }
$$

dilakukan oleh Prathiwi, et al (2014), didapatkan bahwa motivasi belajar dan prestasi belajar IPS siswa yang mengikuti model pembelajaran kooperatif tipe TPS lebih baik daripada motivasi belajar dan prestasi belajar IPS siswa yang mengikuti model pembelajaran konvensional. Motivasi belajar sendiri menurut Sardiman (2008: 75) adalah keseluruhan daya penggerak di dalam diri siswa yang menimbulkan kegiatan belajar, yang menjamin kelangsungan dari kegiatan belajar dan yang memberikan arah pada kegiatan belajar, sehingga tujuan yang dikehendaki oleh subjek belajar itu dapat tercapai. Sehingga dengan adanya motivasi belajar siswa memiliki rangsangan dan dorongan untuk terus memacu dirinya berprestasi dan bersaing dalam kelas dengan sesama temannya.

Tyler (dalam Redhana, 2007) berpendapat bahwa pengalaman atau pembelajaran yang memberikan kesempatan pada siswa untuk memperoleh keterampilan-keterampilan memecahkan masalah dapat merangsang keterampilan berpikir kritis siswa. Tandogan dan Akinoglu (2007) mengungkapkan dengan membiasakan siswa menghadapi masalah maka mereka akan mendapat keterampilan untuk memanagemen waktu, fokus, mengoleksi data, melaporkan persiapan, dan mengevaluasi. Model pembelajaran yang bersifat inovatif dan konstruktivis perlu diterapkan di sekolah.
Model pembelajaran think pair share merupakan model pembelajaran kooperatif yang dirancang untuk mempengaruhi pola interaksi siswa. Model pembelajaran thik pair share dikembangkan oleh Frank Lyman dan Spencer Kagan sebagai struktur kegiatan pembelajaran gotong royong. Menurut Frank Lyman (dalam Arends, 2008) think pair share merupakan model pembelajaran yang dapat mengaktifkan seluruh siswa selama proses pembelajaran dan memberikan kesempatan untuk bekerja sama antar siswa yang mempunyai kemampuan heterogen.

Menurut Arends (2008) model pembelajaran think pair share memiliki tiga tahapan yaitu :

a. Berpikir (thinking)

Guru mengajukan suatu pertanyaan atau masalah yang dikaitkan dengan pelajaran dan meminta siswa menggunakan waktu beberapa menit untuk berpikir sendiri tentang jawaban atas permasalahan tersebut. Siswa membutuhkan penjelasan bahwa berbicara atau mengerjakan bukan bagian berpikir.

b. Berpasangan (pairing)

Guru meminta siswa untuk berpasangan dan mendiskusikan apa yang telah mereka pikirkan. Interaksi selama waktu yang disediakan dapat menyatukan jawaban jika suatu pertanyaan yang diajukan atau menyatukan gagasan apabila suatu masalah khusus yang diidentifikasi. Secara normal guru memberi waktu tidak lebih dari 4 atau 5 menit untuk berpasangan.

c. Berbagi (sharing)

Pada langkah akhir, guru meminta pasangan-pasangan siswa untuk berbagi dengan keseluruhan kelas.

Menurut Solomon (2009) model pembelajaran think pair share adalah praktek pedagogis terbaik karena : (1) memberikan waktu kepada siswa untuk berpikir, ini merupakan periode untuk membayangkan dan menulis jawaban mereka, (2) perilaku waktu latihan, yakni periode untuk berlatih menyatakan pikiran mereka dengan teman sekelas, dan (3) pilihan yang aman dalam berbagi pemikiran kepada mitra belajar. Model pembelajaran think pair share dapat mendorong peningkatan partisipasi siswa dan 
meningkatkan level berpikir dan bertanya siswa.

Multimedia yang umumnya dikenal dewasa ini adalah berbagai macam kombinasi grafik, teks, suara, video, dan animasi. Penggabungaan ini merupakan suatu kesatuan yang secara bersama-sama menampilkan informasi, pesan atau isi pelajaran (Arsyad, 2010:171).

multimedia interaktif merupakan suatu multimedia yang dilengkapi dengan alat pengontrol yang dapat dioperasikan oleh pengguna sehingga pengguna dapat memilih apa yang dikehendaki untuk proses selanjutnya. Contoh multimedia interaktif yaitu: multimedia pembelajaran interaktif, aplikasi game, dan lain-lain. Interaktif berarti bersifat saling mempengaruhi. Artinya antara pengguna (user) dan media (program) ada hubungan timbal balik, user memberikan respon terhadap permintaan atau tampilan media (program), kemudian dilanjutkan dengan penyajian informasi atau konsep berikutnya yang disajikan oleh media (program) tersebut.

Harapan selanjutnya dengan mempelajari IPA, memberikan kesempatan kepada peserta didik untuk mengembangkan potensi mereka menjadi kemampuan yang semakin lama semakin meningkat dalam sikap, pengetahuan, dan keterampilan yang diperlukan dirinya untuk hidup dan untuk bermasyarakat, berbangsa, serta berkontribusi pada kesejahteraan hidup umat manusia.

Berdasarkan pengamatan di lapangan, proses pembelajaran IPA yang dilakukan guru di kelas Usaha Perjalanan Wisata, didapatkan hasil sebagai berikut : (1) Pada saat bel berbunyi tanda pelajaran sudah di mulai, banyak siswa yang masih berada di luar (didepan kelas), menunggu gurunya datang, (2) masih banyak siswa tidak mengeluarkan buku pelajaran dan peralatan untuk belajar, menunggu perintah dari guru untuk mengeluarkan buku dan peralatan belajarnya, (3) siswa kurang memperhatikan proses pembelajaran, ini ditandai dengan adanya siswa yang berbicara dengan temannya diluar konten yang dipelajari, (4) kegiatan belajar mengajar yang terpusat pada guru sehingga terjadi komunikasi satu arah, menyebabkan anak menjadi pasif sehingga menimbulkan rasa bosan dan jenuh, (5) metode ceramah yang dilakukan guru menimbulkan siswa kurang aktif didalam proses belajar mengajar, siswa lebih cendrung diam mendengarkan apa yang disampaikan guru, (6) minat belajar siswa kurang, ditandai dengan jarangnya pertanyaan yang muncul dari siswa serta tanggapan yang diberikan siswa jika ada pertanyaan yang dikemukakan oleh guru, (7) keberanian siswa dalam mengemukakan pendapat masih belum terlihat maksimal dengan sikap yang ragu-ragu untuk menjawab karena takut salah, (8) Sumber belajar yang digunakan masih kurang yaitu hanya menggunakan buku pelajaran dan Lembar Kerja Siswa (LKS), (9) hasil belajar siswa masih banyak dibawah criteria ketuntasan minimal (KKM) berdasarkan hasil ulangan akhir Semester 1 Tahun 2014/2015 pada mata pelajaran IPA, untuk kelas $X$ nilai ratarata IPA 5,60, kelas XI 5,80, dan kelas XII 5,74 . Hasil tersebut masih sangat jauh dari target rata-rata secara umum yaitu 6,70.

Melihat kesenjangan antara harapanharapan yang telah disampaikan dengan kenyataan dilapangan sangat jauh berbeda. Dalam upaya memperbaiki mutu pendidikan utamanya pada mata pelajaran IPA sangat perlu kiranya dilakukan perbaikan cara pembelajaran. Salah satunya adalah perbaikan pembelajaran dengan menggunakan model think pair share berbantuan multimedia interaktif dalam meningkatkan motivasi belajar dan keterampilan berpikir kritis.

Adapun beberapa hasil penelitian yang berhubungan dengan model pengajaran dengan berbantuan media dapat meningkatkan hasil belajar seperti yang dikemukakan oleh Heinich (dalam Iwantara, 2013) menyatakan penggunaan media berbasis multimedia dalam pembelajaran mendatangkan banyak manfaat, yaitu proses pembelajaran dapat berjalan lebih baik, lebih interaktif serta kualitas belajar dapat ditingkatkan.

Menurut Ali (2002) dan Setiawan (2007) bahwa pembelajaran multimedia interaktif merupakan suatu model pembelajaran yang dapat digunakan untuk menyalurkan pesan (message), merangsang pikiran, perasaan, perhatian dan kemauan siswa sehingga dapat 
mendorong proses belajar. Sehingga dengan adanya media pembelajaran multimedia interaktif diharapkan dapat memacu hasil belajar siswa. Ini sejalan dengan hasil penelitian yang dilakukan oleh Permana, et al (2015), dengan model pembelajaran $5 E$ Learning Cycle berbantuan multimedia interaktif menemukan bahwa hasil belajar siswa lebih baik daripada siswa yang hanya diajar dengan model pembelajaran $5 E$ Learning Cycle tanpa bantuan multimedia interaktif.

Multimedia interaktif dapat merangsang rasa ingin tahu siswa dan menumbuhkan motivasi belajar. Motivasi adalah proses yang memberi semangat, arah, dan kegigihan perilaku (Santrock, 2008). Hal tersebut dapat diartikan perilaku yang termotivasi adalah perilaku yang penuh energi, terarah, dan bertahan lama. Hal senada juga disampaikan oleh Glynn \& Koballa (dalam Iwantara, 2013) yang menyatakan motivasi adalah sesuatu yang ada dalam diri siswa yang bersifat membangun, mengarahkan, dan mendukung perilaku siswa. Motivasi ada dua jenis, yaitu motivasi intrinsik dan motivasi ekstrinsik (Djamarah, 2002). Motivasi intrinsik adalah motivasi yang muncul dari dalam diri seseorang untuk melakukan sesuatu. Motivasi ekstrinsik adalah motivasi yang aktif karena adanya rangsangan dari luar.

Rangsangan atau stimulus yang beragam dapat menumbuhkan keterampilan berpikir kritis siswa. Keterampilan berpikir kritis merupakan salah satu outcome yang diharapkan dari pendidikan (Hudgins \& Hedelman (1988); Halpern (1993); dalam Semerci, 2005). Semerci (2005) mengungkapkan bahwa berpikir kritis merupakan sebuah kemampuan yang membantu siswa untuk yakin dalam membuat keputusan untuk hidup mereka. Dengan kata lain, berpikir kritis dapat meningkatkan kemampuan siswa untuk menyesuaikan diri dengan situasi baru, mengembangkan kapasitas penilaian dirinya, serta membantu siswa untuk memperoleh informasi dan melalui pertentangan yang sulit. Jadi, terdapat hubungan yang erat antara motivasi belajar dengan pencapaian hasil belajar siswa. Tyler (dalam Redhana, 2007) berpendapat bahwa pengalaman atau pembelajaran yang memberikan kesempatan pada siswa untuk memperoleh keterampilanketerampilan memecahkan masalah dapat merangsang keterampilan berpikir kritis siswa. Tandogan dan Akinoglu (2007) mengungkapkan dengan membiasakan siswa menghadapi masalah maka mereka akan mendapat keterampilan untuk memanagemen waktu, fokus, mengoleksi data, melaporkan persiapan, dan mengevaluasi. Model pembelajaran yang bersifat inovatif dan konstruktivis perlu diterapkan di sekolah.

Berdasarkan latar belakang yang telah diuraikan, maka dapat dirumuskan permasalahan sebagai berikut. Pertama, Setelah perlakuan dikontol dengan motivasi belajar IPA awal dan keterampilan berpikir kritis awal, apakah terdapat perbedaan motivasi belajar IPA dan keterampilan berpikir kritis siswa secara bersama-sama antara kelompok siswa yang belajar dengan model think pair share berbantuan multimedia interaktif (TPSMI), think pair share (TPS), dan siswa yang belajar menggunakan model pembelajaran langsung (MPL)? Kedua, Setelah perlakuan dikontol dengan motivasi belajar IPA awal dan keterampilan berpikir kritis awal, apakah terdapat perbedaan motivasi belajar IPA siswa antara kelompok siswa yang belajar dengan model think pair share berbantuan multimedia interaktif (TPSMI), think pair share (TPS), dan siswa yang belajar menggunakan model pembelajaran langsung (MPL)? Ketiga, Setelah perlakuan dikontol dengan motivasi belajar IPA awal dan keterampilan berpikir kritis awal, apakah terdapat perbedaan keterampilan berpikir kritis siswa antara kelompok siswa yang belajar dengan model think pair share (TPS) berbantuan multimedia interaktif, think pair share (TPS), dan siswa yang belajar menggunakan model pembelajaran langsung (MPL)?

Sesuai dengan permasalahanpermasalahan yang telah diuraikan tersebut, maka tujuan penelitian ini adalah sebagai. Pertama, Mendeskripsikan perbedaan motivasi belajar IPA dan keterampilan berpikir kritis siswa secara bersama-sama antara kelompok siswa yang belajar dengan model think pair share 
berbantuan multimedia interaktif (TPSMI), think pair share (TPS), dan siswa yang belajar menggunakan model pembelajaran langsung (MPL), setelah perlakuan dikontol dengan motivasi belajar IPA awal dan keterampilan berpikir kritis awal. Kedua, Mendeskripsikan perbedaan motivasi belajar IPA siswa antara kelompok siswa yang belajar dengan model think pair share berbantuan multimedia interaktif (TPSMI), think pair share (TPS), dan siswa yang belajar menggunakan model pembelajaran langsung (MPL), setelah perlakuan dikontol dengan motivasi belajar IPA awal dan keterampilan berpikir kritis awal. Ketiga, Mendeskripsikan perbedaan keterampilan berpikir kritis siswa antara kelompok siswa yang belajar dengan model think pair share berbantuan multimedia interaktif (TPSMI), think pair share (TPS), dan siswa yang belajar menggunakan model pembelajaran langsung (MPL), setelah perlakuan dikontol dengan motivasi belajar IPA awal dan keterampilan berpikir kritis awal.

\section{METODE}

Penelitian ini merupakan penelitian eksperimen semu (quasy experiment). Rancangan penelitian ini menggunakan desain eksperimen the non-equivalent pretest-posttest control group design. Populasi penelitian ini adalah 4 kelas yang terdiri dari 4 jurusan siswa kelas $X$ di SMK Deskripsi umum hasil prates dan pascates motivasi belajar IPA dan keterampilanberpikir kritis siswa terdiri dari
N 1 Singaraja Tahun Pelajaran 2015/2016. Adapun komposisi jumlah siswa kelas $X$ di SMK N 1 Singaraja yang terdiri dari empat jurusan yaitu: Jurusan Usaha Perjalanan Wisata (UPW), Jurusan Akuntansi (AK), Jurusan Tata Niaga (TN), Jurusan Administrasi Perkantoran (AP). Pemilihan sampel dalam penelitian ini dilakukan dengan teknik cluster sampling. Variabel independent berupa model pembelajaran think pair share berbantuan multimedia interaktif (TPSMI), model pembelajaran think pair share (TPS), dan model pembelajaran langsung (MPL). Variabel dependent, yakni motivasi belajar IPA dan keterampilan berpikir kritis siswa. Data dikumpulkan dengan menggunakan angket motivasi belajar IPA terdiri dari 30 butir soal dan tes keterampilan berpikir kritis siswa dengan 25 butir soal pilihan ganda diperluas. Sebelum dilakukan pengujian hipotesis maka data penelitian harus memenuhi syarat analisis yang meliputi uji normalitas data, uji homogenitas data, uji homogenitas matriks varians/covarian, uji linieritas, dan uji kolinieritas antar variabel dependen. Teknik analisis data secara deskriptif dan MANCOVA menggunakan bantuan program SPSS-17.0 for Windows dilanjutkan dengan uji LSD. Pengujian hipotesis pada taraf $5 \%$.

\section{HASIL DAN PEMBAHASAN}

rata-rata (Mean), simpangan baku (SD) disajikan pada Tabel 1.

Tabel 1. Rekapitulasi hasil prates dan pascates motivasi belajar IPA dan keterampilan berpikir kritis siswa

\begin{tabular}{|l|l|l|l|l|l|c|}
\hline \multirow{2}{*}{ Statistik } & \multicolumn{2}{c|}{ TPSMI } & \multicolumn{2}{c|}{ TPS } & \multicolumn{2}{c|}{ PL } \\
\cline { 2 - 7 } & \multicolumn{1}{|c|}{ Pretes } & Postes & Pretes & Postes & \multicolumn{1}{c|}{ Pretes } & Postes \\
\hline Motivasi Belajar & $\mathrm{M}=71,26$ & $\mathrm{M}=79,49$ & $\mathrm{M}=68,74$ & $\mathrm{M}=73,79$ & $\mathrm{M}=66,93$ & $\mathrm{M}=71,57$ \\
IPA & $\mathrm{SD}=5,902$ & $\mathrm{SD}=7,43$ & $\mathrm{SD}=7,519$ & $\mathrm{SD}=8,18$ & $\mathrm{SD}=10,028$ & $\mathrm{SD}=10,62$ \\
\hline Keterampilan & $\mathrm{M}=40,14$ & $\mathrm{M}=67,86$ & $\mathrm{M}=34,98$ & $\mathrm{M}=65,76$ & $\mathrm{M}=34,55$ & $\mathrm{M}=62,88$ \\
Berpikir Kritis & $\mathrm{SD}=2,851$ & $\mathrm{SD}=4,08$ & $\mathrm{SD}=2,78$ & $\mathrm{SD}=3,18$ & $\mathrm{SD}=4,784$ & $\mathrm{SD}=3,73$ \\
\hline
\end{tabular}

Berdasarkan Tabel 1 dapat dinyatakan bahwa secara deskriptif motivasi belajar IPA dan keterampilan berpikir kritis siswa yang belajar dengan menggunakan model think pair share berbantuan multimedia interaktif lebih baik dibandingkan model think pair share dan model pembelajaran langsung

Pengujian Hipotesis

Setelah diketahui bahwa sebaran data normal dan varians homogen, tidak 
terjadi hubungan yang linier, tidak ada hubungan kolinear, matrik varian/kovarian homogen maka analisis MANCOVA untuk menguji hipotesis dapat dilakukan. Ringkasan hasil hipotesis disajikan pada Tabel 2, dan Tabel 3.

Tabel 2. Ringkasan Hasil Uji Multivariat

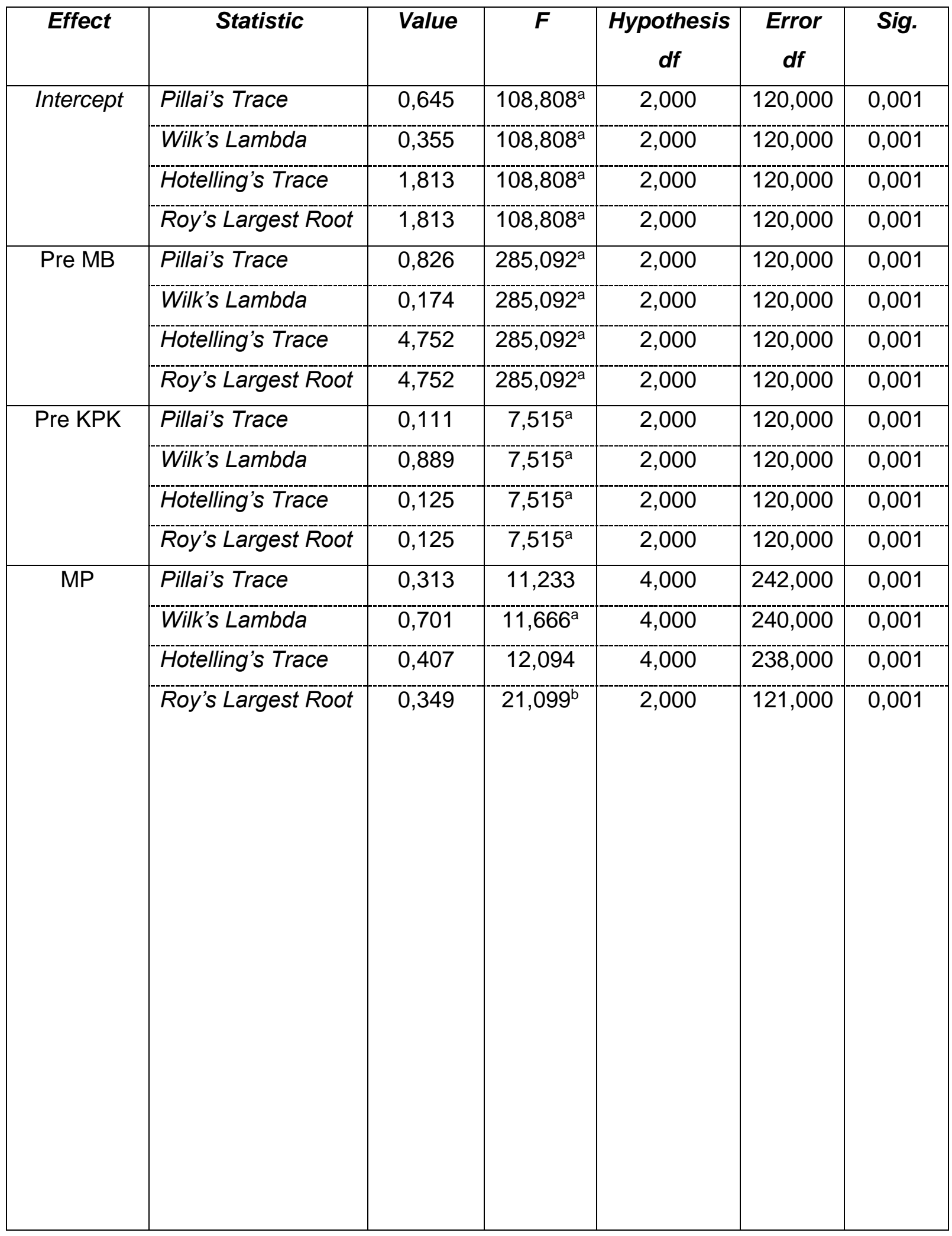


Tabel 3. Ringkasan Hasil Uji Multivariat

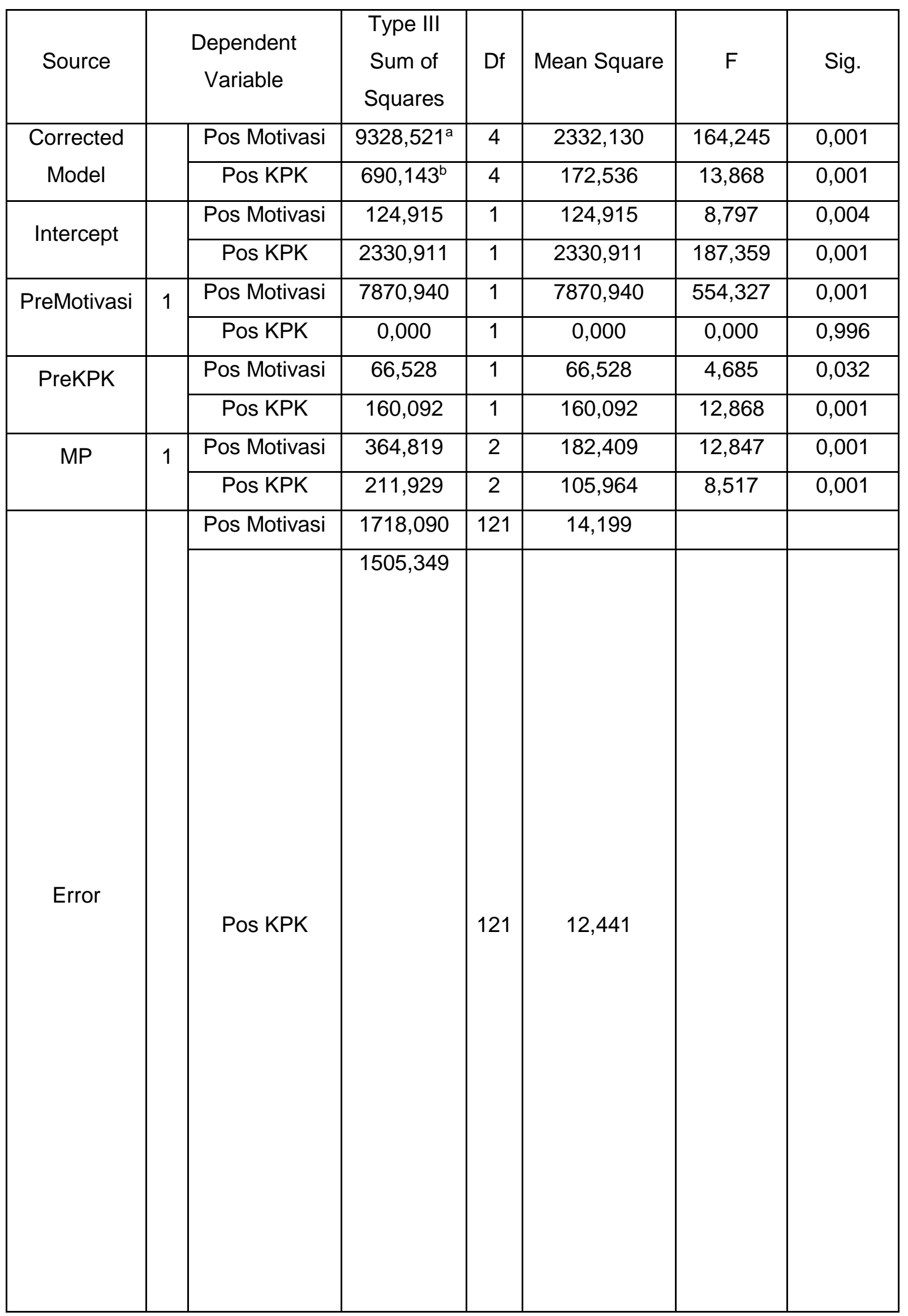


Jurnal Teknologi Pembelajaran Indonesia

ISSN: 2615-2797(Print) | ISSN: 2614-2015 (Online) Volume 8 Nomor 3 Tahun 2018

\begin{tabular}{|l|l|l|l|l|l|l|}
\hline & & & & & & \\
\hline
\end{tabular}


Jurnal Teknologi Pembelajaran Indonesia

ISSN: 2615-2797(Print) | ISSN: 2614-2015 (Online) Volume 8 Nomor 3 Tahun 2018

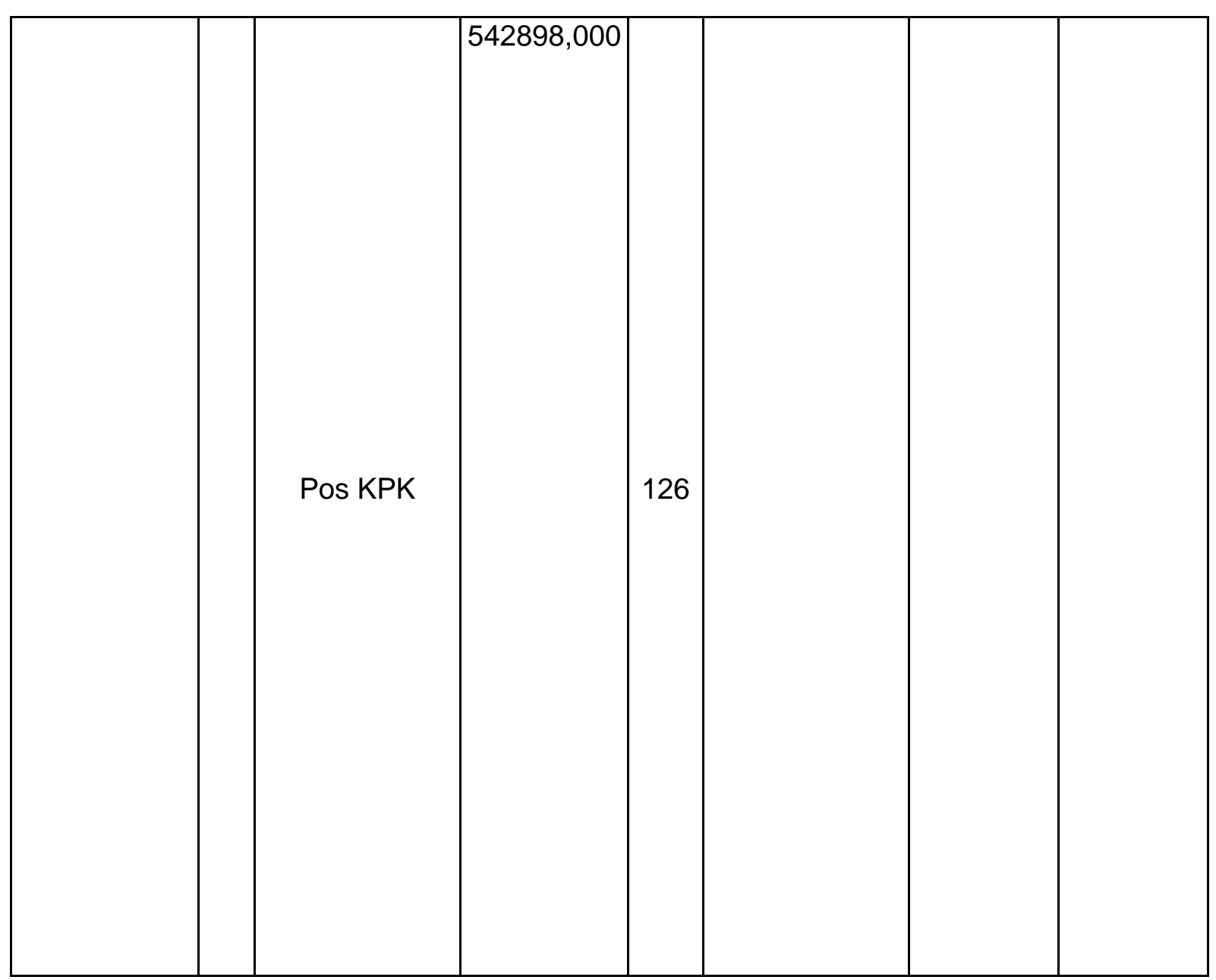


Jurnal Teknologi Pembelajaran Indonesia

ISSN: 2615-2797(Print) | ISSN: 2614-2015 (Online) Volume 8 Nomor 3 Tahun 2018

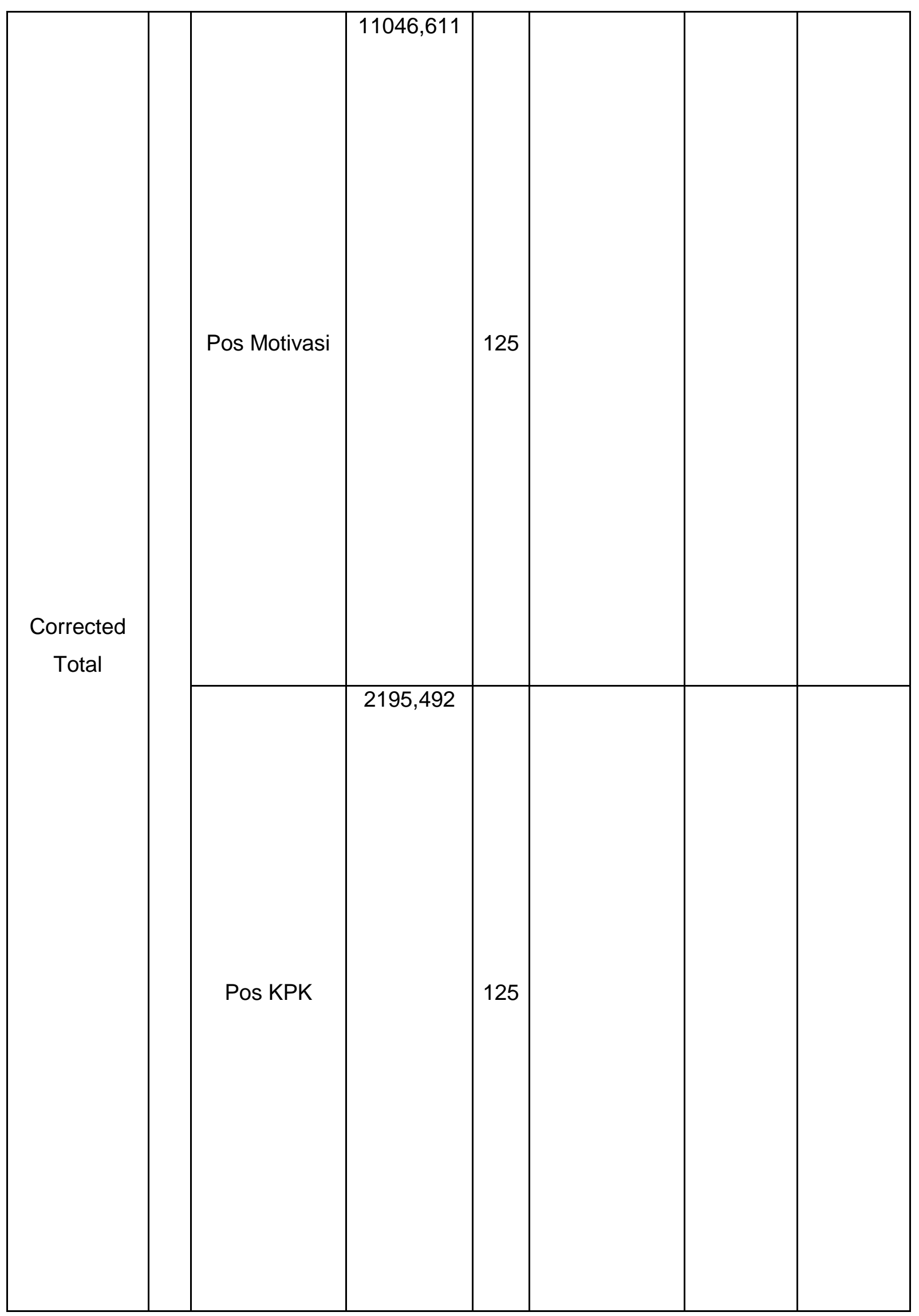


Berdasarkan hasil analisis data penelitian, ditemukan bahwa: (1) setelah perlakuan dikontrol dengan kovariabel motivasi belajar IPA dan keterampilan berpikir kritis siswa terdapat perbedaan yang signifikan motivasi belajar IPA dan keterampilan berpikir kritis siswa antara siswa yang belajar menggunakan model TPSMI, TPS dan PL. (2) setelah perlakuan dikontrol dengan kovariabel motivasi belajar IPA dan keterampilan berpikir kritis siswa terdapat perbedaan yang signifikan motivasi belajar IPA antara siswa yang belajar menggunakan model TPSMI, TPS dan PL. (3) setelah perlakuan dikontrol dengan kovariabel motivasi belajar IPA dan keterampilan berpikir kritis siswa terdapat perbedaan yang signifikan keterampilan berpikir kritis siswa antara siswa yang belajar menggunakan model TPSMI, TPS dan PL.

Hasil yang diperoleh dalam penelitian ini sejalan dengan teori atribusi (Weiner, 1992; 1974), orang-orang yang memiliki kepercayaan diri dalam kemampuan mereka tidak akan melihat tugas yang sulit dan tingkat kecemasan akan relatif rendah. Penggunaan teknologi dapat memotivasi siswa dalam belajar dan memberikan lingkungan belajar yang efektif. Penggunaan teknologi seperti multimedia interaktif dapat meningkatkan motivasi belajar siswa. Siswa lebih termotivasi untuk membangun pengetahuan mereka karena pembelajaran tidak membosankan dengan penyajian materi yang tidak hanya visual tetapi dipadukan dengan audio dan animasi gambar bergerak.

Ghavifekr, et al (2014), pengintegrasikan ICT relevansi dengan kurikulum, menumbuhkan kemampuan berpikir siswa dan terakhir mempromosikan hasil belajar yang lebih baik. Dengan ICT dapat menuntun siswa mencapai hasil belajar yang optimal karena dalam ICT keterampilan berpikir siswa dirangsang untuk memecahkan masalah yang hadapi dalam proses pembelajaran, yang sangat sesuai dengan tuntutan kurikulum pembelajaran untuk mengembangkan kemampuan berpikir kritis dan kreatif.

Dewey (dalam Santyasa, 2012) menganjurkan agar dalam lingkungan belajar, pengajar menciptakan lingkungan sosial yang dicirikan oleh lingkungan demokrasi dan proses ilmiah. Tanggung jawab utama para pengajar adalah memotivasi pebelajar untuk bekerja secara kooperatif dan memikirkan masalah sosial yang berlangsung dalam pembelajaran.

Leow, et al (2014), menemukan bahwa pembelajaran dengan multimedia interaktif, belajar dengan unsur-unsur multimedia lebih fleksibel dalam mengeksplorasi dan membangun pengetahuan baru, mendorong minat belajar yang berpusat pada lingkungan hidup siswa, hasil belajar siswa dan retensi mereka dapat ditingkatkan, membuat pengalaman pembelajaran di kelas lebih bermakna dan layak untuk siswa yang berbeda, siswa menjadi pembelajar mandiri dan menjadi proaktif terhadap proses belajar seluruhnya. Proses pembelajaran yang kompleks mampu menciptakan kondisi belajar yang bermakna, menjadikan siswa lebih berani menghadapi permasalah pembelajaran dan permasalahan dunia nyata.

Sedangkan pada model pembelajaran langsung, proses belajar lebih bersifat Teacher Centered, sehingga peran guru sangat dominan dan kurang efektif dalam menumbuhkembangkan keterampilan (kognitif, afektif, dan psikomotorik) siswa selama proses pembelajaran. Hal ini dapat dilihat dari dominannya pengaruh guru dalam proses belajar mengajar dikelas. Guru memulai pelajaran dengan menyampaikan informasi mengenai tujuan pelajaran dan guru juga menyampaikan keseluruhan materi pelajaran kepada siswa, tanpa memberikan kesempatan pada siswa untuk berperan aktif dalam proses pembelajaran. Suasana pembelajaran yang membosankan akan menurunkan motivasi belajar siswa, sehingga akan berpengaruh pada keterampilan berpikir kritis siswa.

Temuan dalam penelitian ini memberikan petunjuk bahwa pembelajaran dengan model think pair share berbantuan multimedia interaktif memiliki keunggulan komparatif dibandingkan dengan model 
think pair share dan model pembelajaran langsung dalam hal meningkatkan motivasi belajar IPA dan keterampilan berpikir kritis siswa. Berdasarkan hal tersebut maka implikasi yang dapat diberikan dengan multimedia interaktif dalam kegiatan pembelajaran untuk membantu guru mentransfer materi sesuai dengan karakterisk materi, karakteristik guru dan karakteristik siswa. Sehingga berimplikasi pada peningkatan motivasi belajar IPA dan keterampilan berpikir kritis siswa. Keterampilan berpikir kritis sangat penting dilatihkan pada siswa karena keterampilan berpikir kritis sangat diperlukan oleh siswa untuk sukses dalam bidang akademis dan dalam kehidupannya nanti di masyarakat. untuk dapat meningkatkan motivasi belajar IPA dan keterampilan berpikir kritis siswa, maka seorang guru diharapkan bergeser dari paradigma lama yaitu dari seorang narasumber menjadi seorang pengarah, fasilitator dan mediator. Peran guru sebagai pengarah adalah mengarahkan diskusi siswa dengan menyajikan masalah, mengajukan pertanyaan yang tidak terlalu menyimpang dari tujuan pembelajaran. Sebagai fasilitator, guru memfasilitasi kebutuhan siswa akan sumber informasi dan memfasilitasi kegiatan siswa dalam penyelidikan dan dialog. Sebagai mediator guru harus mampu menciptakan suasana pembelajaran yang kondusif dan memilih fitur yang relevan sehingga pembelajaran menjadi menyenangkan. Guru harus mampu mewujudkan langkah-langkah pembelajaran yang inovatif dan kreatif sehingga proses belajar menjadi lebih bermakna.

\section{PENUTUP}

Berdasarkan rumusan masalah, tujuan dan hasil penelitian seperti yang telah diuraikan pada pembahasan, maka dapat disimpulkan sebagai berikut.

Pertama, Setelah perlakuan dikontol dengan motivasi belajar IPA awal dan keterampilan berpikir kritis awal, terdapat perbedaan motivasi belajar IPA dan keterampilan berpikir kritis antara kelompok siswa yang belajar menggunakan model TPSMI, TPS dan PL secara bersamasama. Kedua, Setelah perlakuan dikontol dengan motivasi belajar IPA awal, terdapat perbedaan yang signifikan motivasi belajar IPA antara siswa yang mengikuti model TPSMI, TPS dan PL. Ketiga, Setelah perlakuan dikontol dengan keterampilan berpikir kritis awal, terdapat perbedaan yang signifikan keterampilan berpikir kritis antara siswa yang mengikuti model TPSMI, TPS dan PL.

\section{UCAPAN TERIMA KASIH}

Ucapan terima kasih saya sampaikan kepada Prof. Dr. I Wayan Santyasa, M.Si, sebagai pembimbing I dan I Wayan Sukra Warpala, S.Pd, M.Sc sebagai pembimbing II yang telah dengan sabar membimbing, mengarahkan dan memberikan motivasi sehingga penulis mampu melewati berbagai halangan dan tantangan dalam studi dan penyelesaian

\section{DAFTAR PUSTAKA}

Arsyad, A. 2010. Media pembelajaran. Jakarta: PT Raja Grafindo Persada

Ghavifekr, S., Razak, A. Z. Abd., Ghani, M. F. A., Meixi, Y. \& Tengyue, Z. 2014. ICT Integration In Education: Incorporation for teaching \& learning improvement. The Malaysian Online Journal of Educational Technology. 2(2). 24-45. Tersedia pada : http://www.mojet.net. Diakses : 22 Desember 2015

Iwantara, I W. 2013. Pengaruh penggunaan media video youtobedalam pembelajaran IPA terhadap motivasi belajar dan pemahaman konsep.Tesis.(Tidak diterbitkan). Program Studi Pendidikan IPA Program Pascasarjana Universitas Pendidikan Ganesha.

Leow, F. T. \& Neo, M. 2014. Interactive multimedia learning: innovating classroom education in a malaysian university. The Turkish Online Journal of Educational Technology. 
13(2). 99-110. Tersedia pada: http://www. tojet.net. Diakses : 16 Nopember 2015

Redhana, I W. 2002. Meningkatkan keterampilan berpikir kritis siswa SMU Negeri 4 Singaraja kelas $\|_{1}$ semester 1 tahun ajaran 2002/2003 pada pembelajaran kimia melalui pembelajaran kooperatif dengan strategi pemecahan masalah. Laporan penelitian (tidak diterbitkan). Fakultas Pendidikan MIPA, IKIP Negeri Singaraja.

Santyasa, I W. 2012. Pembelajaran inovatif. Seri Buku Ajar Perguruan Tinggi. Universitas Pendidikan Ganesha.

Semerci, C. 2005. The influence of the Critical Thinking Skills on the Students'Achievement. Pakistan Journal of Social Sciences, 3(4): 598-602.

Suharto. 2015. Materi pelatihan implementasi kurikulum jenjang SMA/SMK. Jakarta: Kemendikbud. 